\title{
т.п. Попович
}

Терезія Петрівна Попович, кандидат юридичних наук, доцент, доцент ДВНЗ «Ужгородський національний університет»*

ORCID: 0000-0002-8333-3921

\section{СОЦІАЛЬНІ ОБОВ'ЯЗКИ: ТЕОРЕТИКО-ПРАВОВІ АСПЕКТИ}

Постановка проблеми. Проблематика соціального обов'язку завжди викликала інтерес філософів та науковців-правників, адже дана категорія втілює у собі ті вимоги, які ставляться перед кожною особою 3 метою встановлення міри належної поведінки, що є необхідною для захисту інтересів інших осіб, суспільства та держави. Тобто наявність соціальних обов'язків виступає необхідною умовою оптимальної та ефективної взаємодії членів суспільства.

Аналіз останніх досліджень і публікацій. Питання, досліджувані у рамках даної статті, є дотичними до тих, які становили предмет наукового аналізу таких науковців, як: О.В. Кабакова, О.П. Карманюк, I.В. Коршунова, С.М. Хохлова, О.П. Черновол, І.Р. Юрчак та ін. Проте дана проблематика все ще залишається дискусійною, викликаючи потребу в подальших доктринальних розвідках.

Формулювання мети статті. Метою даної статті є 3'ясування та розкриття природи соціального обов'язку, генезису та особливостей його різновидів.

Виклад основного матеріалу. 3 огляду на зазначене, категорія «обов’язку», на думку багатьох вчених, $\epsilon$ однією із ключових у юриспруденції. Так, зокрема, Цицерон наголошував на тому, що жодна сфера нашого життя не може бути вільною від обов'язку1, причому слід розуміти, що він розглядає дане поняття не лише в контексті певного зобов'язання перед оточуючими, а й у рамках внутрішнього суб'єктивного сприйняття. Філософ вважав, що у служінні обов'язку і міститься вся моральна краса життя, а нехтування ним - сором.

Розглядаючи поняття загальносоціального обов'язку, зазначимо, що його можна визначити як суспільно визнану необхідність певної поведінки особи (міру належного, корисного), що об'єктивно зумовлена потребами існування й розвитку інших осіб, соціальних груп, націй, людства ${ }^{2}$. Тобто обов язок - це необхідність слідування певній моделі поведінки, що виражається у виконанні певних дій або утриманні від їх здійснення.

Відповідно до філософського енциклопедичного словника, обов'язок - одна з основних категорій етики і моральної свідомості, моральне зобов’язання окремого індивіда, групи осіб, класу, народу та ін., що постає для них як конкретне практичне завдання. Обов'язок - внутрішня настанова людини чинити відповідно до певних моральних норм і цінностей, що існують у суспільстві, своєрідна позитивна ціннісна орієнтація, котра не може здійснюватися без елементу самопримусу, вольового зусилля. Тому виконання обов'язку передбачає наявність свободи волі. Дія, здійснювана під зовнішнім примусом або в результаті насильства, не має етичного значення ${ }^{3}$.

Виходячи із зазначеного, із впевненістю можна стверджувати, що історично соціальні обов'язки виникли разом із появою у людському суспільстві зародків моралі та усвідомлення людиною відповідальності перед родом і плем'ям. Відповідно, з розвитком людства і урізноманітненням соціальних взаємодій інститут обов'язку модифікувався, набуваючи нових рис. Так, якщо в ранні періоди існування людського суспільства неможливо було говорити про їх належність до правового поля з огляду на відсутність будь-якого, бодай мінімального, закріплення даної категорії на нормативному рівні, то надалі розвиток права та законодавства зумовили появу юридично закріплених обов’язків.

Якщо розглядати додержавний період розвитку людства, то зрозуміло, що обов'язки, котрі існували в той період, лежать поза правом та виникали безпосередньо із природи людини, звичаєвих норм, традицій, релігійних догм чи моральних уявлень, базуючись на найпростіших правилах міжособистісної взаємодії.

Розуміючи тривалість формування уявлень людини про обов’язки, зазначимо, що протягом історії розвитку людства щодо питання обов'язків не було єдиної чітко встановленої тенденції, адже в різноманітні часові періоди у різних країнах одні обов'язки закріплювались у законодавчих актах, Конституціях, інші ж базувались виключно на волі громадян, на релігійних нормах суспільства 4 .

Звичайно, згодом у процесі усвідомлення необхідності пошуку оптимальної моделі регулювання суспільних відносин з'явились юридичні механізми забезпечення виконання обов'язків особи перед іншими людьми, суспільством та державою, надаючи їм правовий характер.

Вважається, що першими, хто спробував визначити природу обов’язків, були релігійні проповідники. Мойсей як один із перших законодавців єврейського народу звернув увагу суспільства на категорію обов'язку та визначив їх коло (десять), більш відомих, як десять Божих заповідей. Дані обов'язки стали основою розвитку інституту обов'язків людини і громадянина, як одного із засобів регулювання суспільних відносин. 3 огляду на це, можна зробити висновок, що першим кодифікованим джерелом, яке визначало коло обов'язків людини, стала Біблія5.

() Т.П. Попович, 2020

* Tereziia Popovych, Ph.D. in Law, Associate Professor, Associate Professor of Uzhhorod National University 
На важливість такої категорії, як обов'язки, свого часу звернув увагу і китайський філософ Конфуцій. Особа, за конфуціанськими настановами, має бути членом своєї спільноти, а також - підданим держави, виконуючи свої обов'язки переважно через ретельне додержання правил у рамках своєї мікроспільноти, життєдіяльність якої регулюється державним апаратом. «Що є обов’язком людини? - писав Конфуцій. - Батько повинен проявляти батьківські почуття, а син - шанобливість, старший брат - доброту, а молодший - дружелюбність, чоловік - справедливість, а його дружина - слухняність, старші - милосердя, молодші - покірність, володар - людинолюбство, а піддані - відданість. Ці десять якостей і називаються обов'язком людини»6. Таким чином, Конфуцій наділяв обов'язки морально-змістовними характеристиками, які разом з іншими елементами входили до складу комплексу етико-правових норм та принципів, що й виступали основою регулювання суспільних відносин. Законам у цьому контексті відводилась тільки допоміжна, додаткова роль.

Значно пізніше, але вже зовсім 3 іншого кута зору, поняття обов'язку обгрунтовує німецький філософ С. Пуфендорф у трактаті «Про обов’язки громадянина і людини за природним правом у двох книгах». Характерно, що Пуфендорф чітко розмежовує обов'язки людини і обов'язки громадянина. Перші не припускають ніяких особливих відносин між людьми, інші вимагають наявності певного особливого зв'язку як між особою та державою, так і між громадянами конкретної держави. Тобто обов'язки громадянина - це обов'язки члена певного суспільства, які виникають з владних відносин.

Аналізуючи його позиції, вчені зазначають, що С. Пуфендорф вважав обов'язки людини такими, які мають три джерела: природне право, право цивільне й моральне богослов’я. І це три суттєво різні галузі знання. Для природного права джерелом пізнання є розум. Для права цивільного - позитивні норми законів. Для морального богослов'я - Божественне Одкровення. I тому перше визначає загальні обов'язки людини і громадянина, друге - обов'язки людини і громадянина конкретного громадянського суспільства, третє обов'язки християнина. С. Пуфендорф також розділив обов'язки залежно від об'єкта (осіб, до яких вони звернені) на три групи: обов'язки людини щодо Бога; обов'язки щодо себе самого та обов'язки щодо інших людей («ближніх»). Він вважав, що безпосередньо з «товариськості» (так він іменував притаманну людині потребу жити в суспільстві) виникають обов'язки людини щодо ближніх. Звідси ж він виводить обов'язки щодо Бога, бо найголовніша опора всіх обов'язків людини щодо ближніх, на думку С. Пуфендорфа, це релігія, без якої людська товариськість була б неможливою. Обов'язки людини щодо самої себе випливають 3 товариськості і релігії, без яких людина не може бути ні істинно віруючим, ні корисним членом суспільства7.

Таким чином, очевидно, що залежно від особливостей виникнення конкретних соціальних обов'язків, характеристик суб'єкта, котрий їх встановлює, а також визначає гарантії його реалізації, виокремлюють різновиди соціального обов'язку, серед яких виділяють моральні обов'язки, обов'язки релігійного характеру, корпоративні, професійні, юридичні та інші обов'язки. Причому, вважаємо недоречним абсолютно розмежовувати дані феномени, адже всі вони, як втілення певної соціально необхідної поведінки, пов'язані між собою та можуть вважатись логічним продовженням один одного.

Звертаючись до аналізу окремих змістовних особливостей того чи іншого виду соціальних обов'язків, насамперед зауважимо, що мораль характеризує людину з точки зору іiі здібності до життя в суспільстві. Основними категоріями моральної свідомості є уявлення про добро і зло, любов, щастя, справедливість, обов'язок, моральний конфлікт і моральний вибір8.

Моральні обов'язки закладаються у ранньому віці. Їх обсяг, зміст, засвоєння та виконання залежать не лише від особистісно-суб' єктивних факторів кожного члена суспільства, а й від соціального середовища, в якому відбувається його дорослішання ${ }^{9}$.

Специфікою морального обов'язку є те, що людина сама усвідомлює його сутність і виконує його за власним бажанням, наслідком невиконання якого може бути лише суспільний осуд та нерозуміння 3 боку оточуючих. Тобто у своєму первинному вияві, жодних інших наслідків таке порушення не несе. Проте у процесі своєї трансформації моральний обов'язок здатен модифікуватись у інші види, які передбачають загрозу настання певного виду відповідальності за порушення передбачених вимог.

Якщо говорити про релігійні обов'язки, то релігія, виступаючи як суспільний інститут, ще 3 первісних часів висувала певні вимоги до соціальної поведінки людей, чинила регулятивний вплив на суспільні відносини. Вироблені релігією правила поведінки належать не тільки до сфери здійснення культу, а й до особистого чи суспільного життя людини. Вони мають імперативний характер, впливають на поведінку людей і $\epsilon$ видом соціальних обов'язків. Релігійні обов'язки виступають визначальним елементом у структурі релігійного впливу церкви на своїх послідовників ${ }^{10}$.

Дотримання обов'язків, які передбачені релігійними догмами, як правило, гарантується, з одного боку, повагою суспільства до церкви, внутрішнім переконанням індивідів, що грунтується на вірі в достовірність релігійних приписів, а з іншого, - страхом перед т.зв. «Божою карою», відлученням від церкви, анафемою тощо.

Корпоративні обов'язки існують у межах певного колективу, організації чи професійної спільноти та безпосередньо пов'язані із діяльністю суб'єктів, на яких покладаються конкретні обов'язки. Поведінка зобов'язаних осіб у такій ситуації регулюється т.зв. корпоративними нормами.

Корпоративні норми (це стосується й обов'язків) можуть називатися нормами локальними та навпаки. Однак і ті, й інші одностайно інтерпретуються авторами у сфері теорії права в однаковому розумінні. Локальні норми - це правила, які встановлюються і діють у рамках окремих підприємств, організацій, установ, а також їх структурних підрозділів: виробничих одиниць, цехів, відділів, дільниць, бригад, ферм і т.д. У перекладі з латинської мови термін «локальний» означає місце, місцевий. Корпоративні обов'язки, як і правові обов'язки, текстуально закріплені у відповідних нормативних документах, що мають системний характер. Поширеним прикладом такого документа, на думку більшості авторів, є статут громадської організації ${ }^{11}$. 
У свою чергу, сутність юридичного обов'язку найбільш повно розкривається через категорію «правова необхідність», яка забезпечується можливістю державного примусу. У цілому зміст юридичного обов'язку зводиться до вимоги необхідної, потрібної, корисної з точки зору держави поведінки суб’єкта ${ }^{12}$.

Найчастіше юридичні обов'язки розглядаються в контексті правовідносин, що мають безпосереднє відношення до режиму законності та стану правопорядку в суспільстві, адже суб'єктивний юридичний обов'язок розуміється як вид і міра належної (або необхідної) поведінки суб'єкта права, що встановлені юридичними нормами для задоволення інтересів правомочної особи і забезпечуються державою13.

Таким чином, очевидно, що основною особливістю юридичного обов'язку, порівняно з іншими різновидами соціального обов'язку, є зв'язок з державою та можливість гарантування і забезпечення його реалізації з ії боку. Відповідно, юридичні обов'язки виступають найбільш ефективним засобом стимулювання та виконання суспільно корисної правомірної поведінки всіх учасників суспільних відносин.

Висновки. Отже, узагальнюючи, зазначимо, що під соціальним обов'язком розуміють суспільно визнану необхідність певної поведінки особи, своєрідну міру належного чи корисного, що об'єктивно зумовлена потребами існування і розвитку інших осіб, соціальних груп, націй, людства.

Соціальні обов'язки виникають разом із появою у людському суспільстві зародків моралі. На цьому етапі, звичайно, можна говорити лише про існування моральних обов'язків, котрі у подальшому трансформуються, набуваючи нових сутнісних проявів, з часом отримуючи й нормативне закріплення.

Враховуючи особливості появи, реалізації та способу гарантування окремих соціальних обов'язків, можна виокремити їх види, зокрема, моральні обов'язки, обов'язки релігійного характеру, корпоративні та юридичні обов'язки, котрі володіють як спільними, так і відмінними рисами. Так, безперечно, їх об'єднує спільне призначення, а саме - спрямованість на врегулювання поведінки членів суспільства та вироблення ними певних іï зразків, котрі відповідають вимогам суб'єктів, що їх встановлюють. Проте способи, за допомогою яких вони впливають на зобов'язаних суб'єктів, суттєво відрізняються, так само як і можливості застосування різних засобів забезпечення виконання тих чи інших соціальних зобов'язань.

${ }^{1}$ Цицерон М.Т. Об обязанностях: Философские трактаты. Москва: Наука, 1993 Кн. 1 (репринт текста издания 1974 г.). URL: http://ancientrome.ru/antlitr/t.htm?a $=1423775001$

2 Юрчак І.Р. Обов’язки особи: теоретико-правовий вимір: дис. ... канд. юрид. наук: 12.00.01. Львів, 2016. 185 с. С. 16.

3 Філософський енциклопедичний словник / за ред. В.І. Шинкарука та ін. Київ: Абрис, 2002. 751 с. С. 449.

${ }^{4}$ Кабакова О.В. Конституционные обязаности граждан в России: эволюция правовой регламентации и практика реализации (теоретический и историко-правовой анализ): дисс. ... канд. юрид. наук: 12.00.01. Краснодар, 2006. 240 с. С. 80.

5 Черновол О.П. Юридичні обов'язки людини і громадянина: теоретичні моделі правового забезпечення та реалізації: дис. .... канд. юрид. наук: 12.00.01. Київ, 2019. 192 с. С. $26-27$.

6 Кондратенко Д. Співвідношення особистого та суспільного в конфуціянській етиці. Наукові записки IПіЕНД ім. I.Ф. Кураса НАН Украӥни. 2007. Вип. 40. С. 576-587. С. 577-579.

7 Рождественська О.С. Самуель Пуфендорф та його вчення про обов'язки людини і громадянина. Вісник Харківського начіонального університету імені В.Н. Каразіна. 2011. № 988. Вип. № 10. С. 85-88. С. 86 (Серія «Право»). DOI: 10.26565/2075-5457.

8 Акімова Л.Н., Гаврилюк Р.І. Пороки як відображення аморальної складової моральної свідомості людини. Наука $і$ освіma. 2016. № 7. С. 106-111. С. 107.

9 Коршунова И.В. Обязанность как правовая категория: дисс. ... канд. юрид. наук: 12.00.01. Абакан, 2004. 178 с. С. 36.

10 Луцький І.М. Втілення морально-етичних і релігійних норм у засадничих положеннях Конституції України. Науковоінформаційний вісник «Право». 2012. № 6. С. 16-22. С. 19.

11 Коршунова И.В. Обязанность как правовая категория: дисс. ... канд. юрид. наук: 12.00.01. Абакан, 2004.178 с. С. 51.

12 Хохлова Е.М. Субъективное право и юридическая обязанность в механизме правового регулирования: дисс. ... канд. юрид. наук: 12.00.01. Саратов, 2008. 169 с.

13 Карманюк О.П. Юридичні обов'язки і законність: теоретичні аспекти взаємодії. Science and Education a New Dimension. Humanities and Social Sciences. 2016. IV(16). I.: 95. C. 15-19. C. 15.

\section{Резюме}

Попович Т.П. Соціальні обов'язки: теоретико-правові аспекти.

Стаття присвячена дослідженню природи соціального обов'язку, його генезису та різновидам. Встановлено, що історично соціальні обов'язки виникли разом із появою у людському суспільстві зародків моралі та усвідомлення людьми відповідальності один перед одним у межах своєї спільноти. У подальшому, з розвитком людства і урізноманітненням соціальних взаємодій, інститут обов'язку модифікувався, набуваючи нових рис. Досліджено, що під соціальним обов'язком розуміють суспільно визнану необхідність певної поведінки особи, своєрідну міру належного чи корисного, що об'єктивно зумовлена потребами існування і розвитку інших осіб, соціальних груп, націй, людства.

Також у статті виокремлено особливості різновидів соціального обов'язку, таких як: моральні обов'язки, обов'язки релігійного характеру, корпоративні та юридичні обов'язки.

Ключові слова: обов'язок, соціальний обов'язок, моральний обов'язок, корпоративний обов'язок, релігійний обов'язок, юридичний обов'язок.

\section{Резюме}

Попович Т.П. Социальные обязанности: теоретико-правовые аспекты.

Статья посвящена исследованию природы социального долга, его генезиса и разновидностям. Установлено, что исторически социальные обязанности возникли вместе с появлением в человеческом обществе зародышей морали и осознанием людьми ответственности друг перед другом в рамках своего сообщества. В дальнейшем, с развитием человечества и разнообразием социальных взаимодействий, институт обязанности модифицировался, приобретая новые черты. 
Доказано, что под социальным долгом понимают общественно признанную необходимость определенного поведения лица, своеобразную меру должного или полезного, объективно обусловленную потребностями существования и развития других лиц, социальных групп, наций, человечества.

Также в статье выделены особенности разновидностей социального долга, таких как: моральные обязанности, обязанности религиозного характера, корпоративные и юридические обязанности.

Ключевые слова: обязанность, социальный долг, моральный долг, корпоративный долг, религиозный долг, юридическая обязанность.

\section{Summary}

Tereziia Popovych. Social obligations: theoretical and legal aspects.

The article is devoted to the study of the nature of social obligation, its genesis and variants. It has been established that historically social obligations have arisen with the emergence of the beginnings of morality in human society and the awareness of human responsibility towards one another within their community. In the future, with the development of humanity and the diversity of social interactions, the institute of obligation was modified to take on new features. Thus, if in the early periods of existence of human society, it was impossible to speak about their belonging to the legal field, given the absence of any, at least minimal, fixation of this category at the normative level, then the development of law and legislation led to the emergence of legally binding obligations. It has been researched that social obligation means a socially recognized need for a certain behavior of a person, a kind of proper or useful, which is objectively conditioned by the needs of existence and development of other persons, social groups, nations, humanity.

The article also analyzes that, depending on the particular nature of the emergence of specific social obligations, the characteristics of the subject that establishes them, and defines the guarantees of its implementation, distinguish varieties of social obligation. Allocated moral obligations, religious obligations, corporate, professional, legal and other obligations. Moreover, the author considers it inappropriate to completely differentiate between these phenomena, since all of them, as embodiments of certain socially necessary behavior, are interconnected and can be considered as a logical continuation of each other.

In addition, it is emphasized that the substantive characteristic of a legal obligation as a special type of social obligation is a "legal necessity". The latter, on the one hand, indicates that the obligation exists and develops within the limits of the lawful and statutory conduct required by law. On the other hand, it expresses the content of the obligation and its inherent behavior. The "need" to disclose the obligation plays the same role that the "opportunity" plays in the concept of the rights and freedoms of the individual.

Key words: obligation, social obligation, moral obligation, corporate obligation, religious obligation, legal obligation.

DOI: 10.36695/2219-5521.1.2020.13

УДК 340.155.2:343.26

\section{О.В. СОКАЛЬСЬКА}

Олена Володимирівна Сокальська, кандидат юридичних наук, доцент*

ORCID: 0000-0001-8737-0829

\section{АНГЛІЙСЬКІ ТЮРЕМНІ ПРОЄКТИ: БІЛЛЬ ПРО КАТОРЖНІ РОБОТИ 1778 РОКУ ТА ПЕНІТЕНЦІАРНИЙ АКТ 1779 РОКУ}

Постановка проблеми. Дослідження витоків формування пенітенціарних систем та концепту виправного покарання видається достатньо актуальним з огляду на триваючу реформу вітчизняної системи виконання покарань, пошук ії зразкової моделі, дискусії щодо термінології (пенітенціарний $v s$ кримінально-виконавчий), а також брак у вітчизняній історіографії досліджень з історії пенітенціаристики та контроверсійність думок у зарубіжній пенології щодо авторства Пенітенціарного акта 1779 року.

Формулювання мети статті. Метою даної розвідки є аналіз пам'яток англійського права: законопроєкту про каторжні роботи 1778 р. та Пенітенціарного акта 1779 р., визначення передумов їх ухвалення, джерел та основних положень.

Аналіз останніх досліджень та публікацій. Джерельною базою дослідження стали праці англійських тюрмознавців Б. Уебб, С. Уебб, Ш. Мак-Конвіла, Л. Тронесс, грунтовна розвідка витоків Пенітенціарного акта 1779 р. С. Деверо, законопроєкт про каторжні роботи 1778 р., текст якого узято з роботи Дж. Бентама $A$ View of the Hard Labour Bill, та Пенітенціарний акт 1779 року.

Виклад основного матеріалу. Попри загальновідому жорстокість англійської системи покарань XVIII ст., слід зазначити, що в Англії у цей період боротьба зі злочинністю, фактично, обмежувалася висилкою засуджених за межі метрополії: «немає злочинця - немає проблеми». Смертна кара «боролася зі злочинністю» за таким же принципом. Але, незважаючи на те, що передбачалась вона більш ніж за 200 злочинів (від дрібної крадіжки до вбивства), судді у кінці XVIII ст., виносячи вироки, присуджували таких злочинців переважно до транспортації1.

3 початком війни Північно-Американських колоній за незалежність довелося шукати альтернативу транспортації. Розміщення засуджених до траснпортації на кораблях (так званих плавучих тюрмах, або халках), було тимчасовим рішенням проблеми. Планувалося, що після припинення війни, транспортація буде

\footnotetext{
О.В. Сокальська, 2020

* Olena Sokalska, Ph.D. in Law, Associate Professor
} 